Huda et al., Ind. J. Chem. Anal., Vol. 01, No 01, 2018, pp. 09-19

\title{
Kajian Adsorpsi Methylene Blue Menggunakan Selulosa dari Alang-Alang
}

\author{
Thorikul Huda* , Tantri Kurnia Yulitaningtyas \\ Program Studi D3 Analisis Kimia, Fakultas Ilmu Pengetahuan Alam dan Matematika, Universitas Islam Indonesia \\ *corresponding author : thorikul.huda@uii.ac.id
}

\begin{tabular}{|c|c|}
\hline ARTIKEL INFO & ABSTRAK \\
\hline $\begin{array}{l}\text { Received : } 05 \text { Juli } 2018 \\
\text { Revised : } 01 \text { Agustus } 2018 \\
\text { Published : } 28 \text { September } 2018 \\
\text { Kata Kunci :selulosa alang-alang, } \\
\text { interaksi adsorpsi, kinetika adsorpsi, } \\
\text { isoterm adsorpsi, methylene blue. }\end{array}$ & $\begin{array}{l}\text { Telah dilakukan studi kajian adsorpsi methylene blue menggunakan } \\
\text { selulosa dari alang-alang. Kajian ini memiliki tujuan untuk } \\
\text { menentukan kapasitas adasorpsi dan mengetahui karakteristik } \\
\text { penggunaan selulosa tanaman alang-alang sebagai adsorben pada } \\
\text { degradasi zat warna methylene blueterhaap pH optimum dengan laju } \\
\text { kinetika adsorpsi pada variasi waktu kontak, dan isoterm adsorpsi } \\
\text { terhadap konsentrasi optimum, serta jenis interaksi yang terjadi. } \\
\text { Prinsip dari analisis ini yaitu didasarkan pada pengukuran absorbansi } \\
\text { dari zat warana methylene blue sebelum adsorpsi dan setelah adsorpsi } \\
\text { dengan menggunakan Spektrofotometer UV-Vis single beam pada } \\
\text { panjang gelombang } 665 \text { nm. Larutan standar dibuat dengan rentang } \\
\text { konsentrasi } 0,1,2,3,4,5 \text { ppm dan menghasilkan persamaan garis } \\
\text { lurus y = 0,218x-0,001 dengan koefisien determinasi (R }{ }^{2} \text { ) adalah } \\
\text { 0,998. Hasil analisis menunjukan bahwa adsorben selulosa dari } \\
\text { tanaman alang-alang mampu mengadsorpsi zat warna methylene blue } \\
\text { dalam suasana basa pH } 9 \text { dengan laju kinetika pada orde dua dan } \\
\text { cenderung interaksi multileyer atau prinsip isoterm adsorpsi } \\
\text { freundlich.Interaksi adasorpsi yang terjadi karena adanya adsorpsi } \\
\text { fisika. Kapasitas adsorpsi dari masing-masing metode secara } \\
\text { berturut-turut sebsar 26,4472 mg/g dan 26,6758 mg/g. Adsorpsi } \\
\text { alang-alang terhadap zat warna methylene blue tidak berpengaruh } \\
\text { pada struktur selulosa dari alang-alang dan gugus yang terdapat pada } \\
\text { alang-alang yaitu O-H, C-H, dan C-O. }\end{array}$ \\
\hline
\end{tabular}

\section{PENDAHULUAN}

Perkembangan ilmu pengetahuan dan teknologi memberikan banyak keuntungan bagi kehidupan manusia, namun efek yang ditimbulkan memberikan dampak negatif bagi lingkungan sekitarnnya, misalnya masalah limbah industri. Limbah industri jika tidak dikelola dengan baik dan dibuang begitu saja secara bebas maka akan menyebabkan air yang terdapat di lingkungan sekitarnnya tercemar. Produksi industri tektil Indonesia yang berupa bahan tekstil, produk tekstil, dan industri pakaian jadi merupakan penyumbang divisa nomor satu di sektor non migas dan nomor tiga setelah minyak bumi dan gas alam. Pada masa krisis ekonomi, industri tekstil ini terbukti mempunya daya tahan cukup tinggi sehingga diharapkan produksinya terus meningkat seiring dengan meningkatnya kebutuhan dalam negeri serta kemudahan-kemudahan ekspor dan impor bahan baku yang diberikan oleh pemerintah. Tuntutan kenaikan produksi tekstil ini diharapkan dapat diikuti dengan pemenuhan kewajiban pihak-pihak terkait untuk setidaknya dapat mereduksi dampak negatif yang mungkin timbul. Akibat teknis yang mungkin timbul adalah meningkatnya kuantitas dan kualitas bahan buangan atau limbah. Dampak negatif industri tekstil terutama berasal dari proses pencelupan (dyeing)[1].

Pada proses pencelupan tekstil dihasilkan sekitar $24 \%$ zat warna dan $6 \%$ garam yang digunakan pada pewarnaan yang kemudian masuk ke lingkungan perairan sebagai limbah[2]. Warna limbah muncul karena adanya gugus kromofor dalam zat warna tekstil yang digunakan pada proses pencelupan. Limbah hasil pencelupan yang dibuang menyebabkan kualitas air akan menurun sehingga 
Huda et al., Ind. J. Chem. Anal., Vol. 01, No 01, 2018, pp. 09-19

tidak sesuai lagi dengann peruntukkannya dan ekosistem lingkungan akan terganggu. Selain sulit diuraikan, bahan aktif zat warna seperti azo (monoazo, diazo, triazo) dilaporkan bersifat karsinogenik[1].

Dampak yang ditimbulkan dari zat warna sintetik begitu mempengaruhi lingkungan sekitar dan kesehatan manusia, maka diperlukan suatu upaya untuk mengurangi dampak pencemaran dari zat warna tersebut. Salah satu upaya untuk mengurangi pencemaran adalah dengan metode adsorpsi menggunakan adsorben. Pemanfaatan limbah yang berasal dari pertanian merupakan salah satu cara dalam mengatasi permasalahan pencemaran ini. Limbah pertanian yang berupa tongkol jagung, tempurung kelapa, ampas tebu, kulit buah, dan tanaman liar seperti enceng gondok dan alang-alang dapat dijadika adsorben. Tentunya dengan memanfaatkan limbah, maka pembuatan adsorben ini menjadi lebih murah, bahan yang dipakai berlimpah dan mudah ditemukan.

Alang-alang (Imperata cylindrica) merupakan tanaman liar yang dapat tumbuh di daerah tropik dan subtropik. Tanaman ini banyak dimanfaatkan oleh kebanyakan orang sebagai obat herbal diantaranya adalah obat demam, darah tinggi, muntah, radang ginjal, pembersih darah akut, sesak nafas, kencing nanah, mimisan, dan gangguan fungsi hati[3]. Bagian tanaman yang digunakan hanyalah akarnya berupa umbi sedangkan daun dari tanaman ini dibiarkan begitu saja padahal daun yang dihasilkan pada tanaman alang-alang dapat dimanfaatkan sebagai adsorben. Alang-alang digunakan sebagai adsorben karena mempunyai kandungan selulosa yang cukup tinggi meliputi alfa selulosa 56,21\% dan holo selulosa 35,41\%[4].Adsorpsi menggunakan selulosa dan hemiselulosa pada gugus hidroksil akan berinteraksi dengan gugus azo pada zat warana methylene blue.

Methylene blue (MB) merupakan zat warna dasar yang sangat penting dan relatif murah dibandingkan dengan pewarna lainnya. Zat warna ini papling sering dipakai dalam industri testil, sutra, wool, dan kosmetik. Dosisi tinggi dari MB dapat menyebabkan mual, muntah, nyeri pada perut dan dada, sakit kepala, keringat berlebihan, dan hipertensi. Selain itu, methylene blue juga dapat menyebabkan iritasi pada saluran pencernaan jika tertelan, menimbulkan sianosis jika terhirup, dan iritasi pada kulit jika tersentuh oleh kulit[5].

\section{METODELOGI PENELITIAN}

\subsection{Alat}

Alat-alat yang digunakan dalam penelitian antara lain : oven, instrumen spektrofotometer UVVis single beam, magnetic stirrer, seperangkat alat refluks, $\mathrm{pH}$ meter, spatula, blender, saringan mesh, dan alat gelas (pipet ukur $1 \mathrm{~mL} ; 10 \mathrm{~mL} ; 25 \mathrm{~mL}$, pro-pipet, pipet tetes, gelas piala $250 \mathrm{~mL} ; 500$ $\mathrm{mL}$, labu ukur $10 \mathrm{~mL} ; 250 \mathrm{~mL} ; 500 \mathrm{~mL}$, corong gelas, pengaduk kaca, dan cawan porselen).

\subsection{Bahan}

Bahan-bahan yang digunakan dalam penelitian ini antara lain : alang-alang, methylen blue, asam klorida $(\mathrm{HCl}) 1 \mathrm{~N}$, asam klorida $(\mathrm{HCl}) 2 \mathrm{M}$, natrium hidroksida $(\mathrm{NaOH}) 1 \mathrm{~N}$, akuades, kertas whatman No. 42.

\subsection{ProsedurKerja}

\subsubsection{Pembuatan Adsorben Alang-alang}

\subsubsection{Preparasi Selulosa Alang-Alang Metode Stirrer}

Daun alang-alang dicuci bersih dan dikeringkan, kemudian dimasukkan ke dalam mesin penyerbuk dan diayak menggunakan saringan mesh dengan ukuran 80 mesh. Daun alang-alang yang telah halus ditimbang sebanyak 25 gram dan ditambahkan $250 \mathrm{~mL}$ larutan $\mathrm{HCl} 2 \mathrm{M}$. Campuran distirrer selama 3 jam. Setelah itu, padatan dicuci dengan akuades sampai netral (bebas asam), disaring, dan dikeringkan pada suhu $100-105^{\circ} \mathrm{C}$ selama semalam.

\subsubsection{Preparasi Selulosa Alang-alang dengan Metode Refluks}

Daun alang-alang dicuci bersih dan dikeringkan, kemudian dimasukkan ke dalam mesin penyerbuk dan diayak menggunakan saringan mesh dengan ukuran 80 mesh. Daun alang-alang yang telah halus ditimbang sebanyak 25 gram dan ditambahkan $250 \mathrm{~mL}$ larutan $\mathrm{HCl} 2 \mathrm{M}$. Campuran direfluks pada temparatur $80^{\circ} \mathrm{C}$ selama $3 \mathrm{jam}$. Setelah itu, padatan dicuci dengan akuades sampai netral (bebas asam), disaring, dan dikeringkan pada suhu $100-105^{\circ} \mathrm{C}$ selama semalam. 


\subsubsection{Pembuatan Larutan Baku Metilen Biru 100 ppm}

Serbuk metilen biru sebanyak $10 \mathrm{mg}$ dilarutkan dengan $25 \mathrm{~mL}$ akuades. Larutan tersebut dipindahkan ke dalam labu ukur $100 \mathrm{~mL}$ dan diencerkan menggunakan akuades hingga volume 1/3 di bawah tanda batas. Sebelum ditepatkan, larutan dalam labu ukur diseka terlebih dahulu agar tidak ada penambahan volume yang menyebabkan perubahan konsentrasi. Kemudian larutan dihomogenkan.

\subsubsection{Penentuan Panjang Gelombang}

Pada penentuan panjang gelombang ini yang dilakukan adalah detekasi absorbansi pada larutan standar rentang panjang gelombang 650-700 $\mathrm{nm}$ menggunakan spektrofotometer UV-Vis. Setelah itu dibuat kurva standar yang menghubungkan antara konsentrasi dari amsing-masing larutan standar dengan absorbansi yang telah didapat.

\subsubsection{Pembuatan Kurva Standar}

Larutan deret standar dengan konsentrasi $1 ; 2 ; 3 ; 4 ; 5$ ppm dibuat dari larutan induk metilen biru 100 ppm yang dilarutkan dalam $25 \mathrm{~mL}$ akuades.

\subsubsection{Degradasi Zat Warna dengan Metode Adsorpsi \\ 2.3.2.1. Penentuan pH Optimum}

Serbuk alang-alang sebanyak $20 \mathrm{mg}$ dimasukkan ke dalam $10 \mathrm{~mL}$ larutan methylen blue 100 $\mathrm{mg} / \mathrm{L}$ dengan variasi $\mathrm{pH} 2 ; 3 ; 4 ; 5 ; 6 ; 7 ; 8 ; 9 ; 10 ; 11$. Gelas piala ditutup dengan plastik, digojok dengan magnetic stirrer selama 24 jam. Adsorben dipisahkan dari larutan dengan menyaring menggunakan kertas saring wahtman 42. Filtrat yang diperoleh, dipipet sebanyak $0,5 \mathrm{~mL}$ dan dimasukkan ke dalam labu ukur $10 \mathrm{~mL}$, kemudian ditambah akuades sampai tanda batas. Konsentrasi methylen blue sebelum dan sesudah ditentukan dengan spektrofotometer UV-Vis. Nilai kapasitas adsorpsi dihitung berdasarkan jumlah methylen blue yang teradsorp pada adsorben.

\subsubsection{Penentuan Waktu Kontak Optimum}

Serbuk alang-alang sebanyak $20 \mathrm{mg}$ dimasukkan ke dalam $10 \mathrm{~mL}$ larutan methylen blue 100 $\mathrm{mg} / \mathrm{L}$ dengan variasi waktu kontak 0,$5 ; 1 ; 3 ; 5 ; 9 ; 11 ; 13$ jam. Gelas piala ditutup dengan plastik, digojok dengan magnetic stirrer selama 24 jam. Adsorben dipisahkan dari larutan dengan menyaring menggunakan kertas saring wahtman 42. Filtrat yang diperoleh, dipipet sebanyak $0,5 \mathrm{~mL}$ dan dimasukkan ke dalam labu ukur $10 \mathrm{~mL}$, kemudian ditambah akuades sampai tanda batas. Konsentrasi methylen blue sebelum dan sesudah ditentukan dengan spektrofotometer UV-Vis. Nilai kapasitas adsorpsi dihitung berdasarkan jumlah methylen blue yang teradsorp pada adsorben.

\subsubsection{Penentuan Konsentrasi Optimum}

Serbuk alang-alang sebanyak $20 \mathrm{mg}$ dimasukkan ke dalam $10 \mathrm{~mL}$ larutan methylen blue 100 $\mathrm{mg} / \mathrm{L}$ dengan konsentasi $40 ; 80 ; 100 ; 120 ; 140 ; 160 ; 200$ ppm. Gelas piala ditutup dengan plastik, digijok dengan magnetic stirrer selama 24 jam. Adsorben dipisahkan dari larutan dengan menyaring menggunakan kertas saring wahtman 42. Filtrat yang diperoleh, dipipet sebanyak $0,5 \mathrm{~mL}$ dan dimasukkan ke dalam labu ukur $10 \mathrm{~mL}$, kemudian ditambah akuades sampai tanda batas. Konsentrasi methylen blue sebelum dan sesudah ditentukan dengan spektrofotometer UV-Vis. Nilai kapasitas adsorpsi dihitung berdasarkan jumlah methylen blue yang teradsorp pada adsorben.

\subsubsection{Pengujian FTIR}

Setelah diketahui nilai $\mathrm{pH}$ optimum, waktu kontak optimum, dan konsentrasi optimum, masing-masing residu serbuk alang-alang dari proses stirrer dan refluks dilakukan analisa sebelum dan setelah adsorpsi terhadap methylen blue dengan menggunakan spektrofotometri FTIR. Pengujian ini dilakukan pada bilangan gelombang $400-4000 \mathrm{~cm}^{-1}$. 
Huda et al., Ind. J. Chem. Anal., Vol. 01, No 01, 2018, pp. 09-19

\section{HASIL PENELITIAN}

\subsection{Karakteristik Selulosa dari Alang-alang}

Serbuk alang-alang diaktivasi dengan menggunakan asam kuat berupa asam klosrida $2 \mathrm{M}$. Akativasi dilakukan untuk membuat pori pada selulosa meningkat sehingga kapasitas adsorpsi selulosa dari alang-alang semakin besar. Larutan asam klorida merupakan asam kuat yang dapat digunakan untuk meluruhkan ikataa hemiselulosa dengan selulosa pada alang-alang. Selulosa alangalang sebagai adsorben zat warna methylene blue menggunakan prinsp adsorpsi fisika.

Peristiwa adsorpsi selulosa alang-alang terjadi karena adanya gaya Van der Walls yaitu gaya tarik-mrnarik intermolekul antara molekul padatan dengan solut yang diadsorpsi lebih besar daripada gaya tarik-menarik sesam solute itu seniri di dalam larutan, maka solute akan terkonsentrasi pada permukaan padatan. Adsorpsi jenis ini tidak bersifat site spesific, dimana molekul yang teradsorpsi bebas untuk menutupi seluruh permukaan padatan[6].

\subsection{Penentuan Panjang Gelobang Maksimum}

Panjang gelombang maksimum ditentukan untuk mengetahui titik daerah serapan terbesar dari konsentrasi larutan standar. Pengukuran ini dilakukan pada panjang gelombang maksimum sehingga sesnditivitas alat juga akan maksimum dan diharapkan perubahan adsorpsi sampel pers atuan konsentrasi adalah yang terbesar. Selain itu, pita adsorpsi disekitar panjang gelombang rata, sehingga kepekaan analisi menjadi lebih baik dan pengaturan ulang panjang gelombang akan menghasilkan kesalahan analisis yang kecil[7].

Penentuan panjang gelombang dari larutan methylene blue dilakukan dengan larutan standar 3 ppm dan diukur absorbansinya pada panjang gelombang 650-670 nm. Hal ini dikarenakan warna komplementer biru untuk methylene blue ada pada rentang panjang gelombang tersebut dan larutan standar tersebut digunakan agar hasil yang diperoleh tidak terlalu besar dan terlalu kecil.

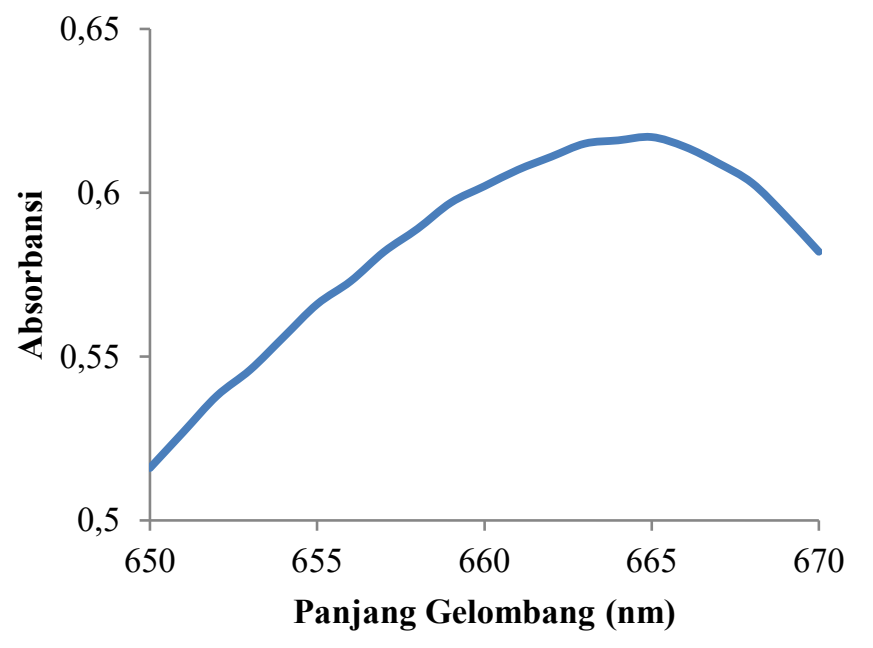

Gambar 1. Kurva Menunjukkan Optimasi Panjang Gelombang

Menurut data hasil pengukuran terkait kurva penentuan panjang gelombang yang ditunjukan oleh Gambar 1 diperoleh panjang gelombang maksimum $665 \mathrm{~nm}$ dengan nilai absorbansi 0,617. Hasil tersebut sesuai dengan literatur yang dilakukan oleh[8].

\subsection{Kurva Kalibrasi}

Konsentrasi suatu analit ditentukan dengan penentuan kurva kalibrasi, yaitu dengan membuat beberapa larutan standar yang telah diketahui konsentrasinya. Deret larutan standar 0, 1, 2, 3, 4, dan 5 ppm diukur nilai absorbansinya sebanyak tiga kali pembacaan pada panjang gelombang $665 \mathrm{~nm}$ dapat dilihat pada Tabel 1 
Huda et al., Ind. J. Chem. Anal., Vol. 01, No 01, 2018, pp. 09-19

TABEL 1. Absorbansi Rerata Larutan Standar Mthylene Blue

\begin{tabular}{cc}
\hline Konsentrasi Methylene Blue $\mathbf{( p p m )}$ & Absorbansi \\
\hline 0 & 0 \\
1 & 0,22 \\
2 & 0,418 \\
3 & 0,666 \\
4 & 0,892 \\
5 & 1,079 \\
\hline
\end{tabular}

Nilai absorbansi tersebut dibuat kurva seperti Gambar 2, antara konsentrasi sebagai sumbu x dan absorbansi sebagai sumbu y sehingga akan diperoleh persamaan untuk menghitung konsentrasi dalam sampel.

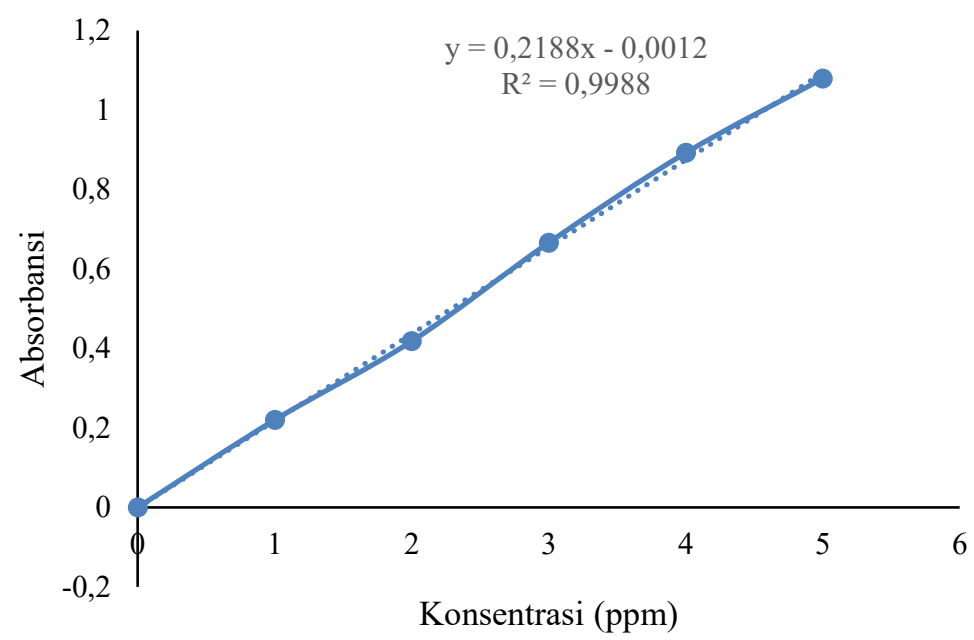

Gambar 2. Kurva Hubungan Absorbansi terhadap Konsentrasi

Kurva Kalibrasi standar methylene blue yang menunjukkan hubungan absorbansi berbanding lurus dengan konsentrasi. Artinya semakin besar konsentrasi larutan standar maka semakin besar pula nilai ansorbansinya. Persamaan regresi linear yang diperoleh yaitu, $y=0,218 \mathrm{x}-0,001$ dengan koefisien determinasi $\left(\mathrm{R}^{2}\right)$ adalah 0,998 . Hal ini menandakan nilai koefisien determinasi yang diperoleh baik karena mendekati nilai 1 . Nilai koefisien determinasi menunjukkan kelayakan penggunaan grafik dalam pengujian.

\subsection{Pengaruh Variasi pH}

Penentuan $\mathrm{pH}$ optimum dilakukan dengan cara mengatur $\mathrm{pH}$ larutan zat warna methylene blue. Pengaturan $\mathrm{pH}$ dengan menambahkan $\mathrm{HCl}$ atau $\mathrm{NaOH}$ sehingga diperoleh $\mathrm{pH} 2 ; 3 ; 4 ; 5 ; 6 ; 7 ; 8$; $9 ; 10 ; 11$. Variasi $\mathrm{pH}$ optimum ditentukan untuk mengetahui kemampuan daya adsorpsi alang-alang terhadap senyawa methylene blue, sehingga fungsi adsorben tersebut dapat digunakan dengan baik terhadap lingkungan (Tabel 2).

TABEL 2. Hasil Pengukuran $\mathrm{pH}$ terhadap Adsorpsi Alang-alang

\begin{tabular}{cccc}
\hline \multirow{2}{*}{$\mathbf{p H}$} & $\begin{array}{c}\text { C teoritis } \\
(\mathbf{m g} / \mathbf{L})\end{array}$ & Stirrer & \%Ads \\
\cline { 3 - 4 } & 100 & 47,7221 & Refluk \\
\hline 2 & 100 & 25,1898 & 55,4144 \\
3 & 100 & 27,1988 & 41,9409 \\
4 & 100 & 51,7448 & 39,2447 \\
5 & 100 & 67,7215 & 24,4284 \\
6 & & & 53,7974 \\
\hline
\end{tabular}

Copyright (C) 2018, Indonesian Journal of Chemical Analysis, ISSN 2622-7401, e ISSN 2622-7126 
Huda et al., Ind. J. Chem. Anal., Vol. 01, No 01, 2018, pp. 09-19

\begin{tabular}{cccc}
\hline 7 & 100 & 81,8025 & 64,9785 \\
8 & 100 & 92,3433 & 100 \\
9 & 100 & 100 & 100 \\
10 & 100 & 96,9471 & 99,0099 \\
11 & 100 & 98,5755 & 96,2963 \\
\hline
\end{tabular}

Kurva $\mathrm{pH}$ optimum didapatkan dengan cara memplotkan antara $\mathrm{pH}$ dengan persentase adsorpsi alangalang terhadap larutan methylene blue (\%Ads) ditunjukkan pada Gambar 3.

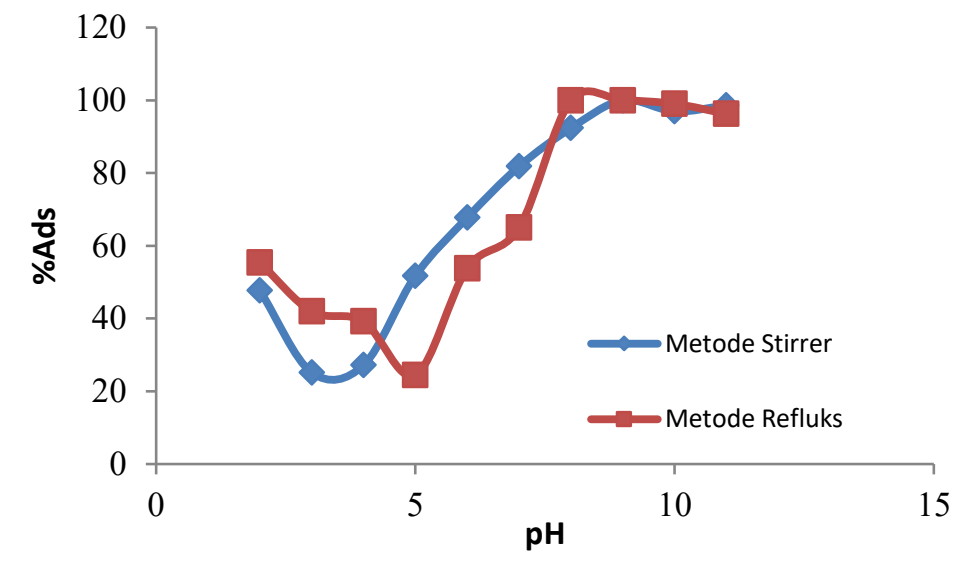

Gambar 3. Kurva Menunjukkan Waktu Kontak Optimum

Proses adsorpsi zat warna methylene blue dalam kondisi basa pada $\mathrm{pH} 9$ dimana alang-alang dapat menyerap biru metilen secara optimal baik pada metode stirrer maupun metode refluks, seperti yang ditunjukkan pada Gambar 3. Hasil persentase adsorpsi dari kedua metode pun sama yaitu 100\% yang artinya terjadi kesetimbangan antara ion azo dye dengan ion hidroksil dalam larutan sehingga terjadi penyerapan zat warna oleh alang-alang. Selain itu, sifat dari selulosa itu sendiri yang dapat dengan mudah bereaksi pada kondisi basa dan zat warna yang dihasilkan oleh limbah tekstil pun memiliki suasana basa karena pada proses pencelupan terjadi pada $\mathrm{pH}$ 9-11.

\subsection{Kinetika Adsorpsi Terhadap Waktu Kontak}

Waktu kontak adalah waktu yang dibutuhkan alang-alang untuk mengadsorpsi zat warna methylene blue. Penentuan waktu kontak optimum dilakukan dengan memvariasikan waktu pada saat pengontakan antara alang-alang dengan zat warna methylene blue $100 \mathrm{ppm}$ yang dimulai dari 0,$5 ; 1$; $3 ; 5 ; 9 ; 11 ; 13$ jam pada suasana basa yaitu $\mathrm{pH}$ 9. Penentuan waktu kontak optimum dilakukan tiga kali pengulangan setiap variasi waktu. Hal ini dilakukan agar pengukuran valid sehingga akan didapatkan waktu optimum yang akan digunakan untuk menentukan konsentrasi optimum (Tabel 3).

TABEL 3. Hasil Pengukuran Waktu Kontak terhadap Adsorpsi Alang-alang

\begin{tabular}{cccccc}
\hline \multirow{2}{*}{$\mathbf{t}(\mathbf{j a m})$} & \multirow{2}{*}{$\mathbf{C}$ teoritis $(\mathbf{m g} / \mathbf{L})$} & \multicolumn{2}{c}{ \%Ads } & \multicolumn{2}{c}{$\mathbf{q}$} \\
\cline { 3 - 6 } & & Stirrer & Refluk & Stirrer & Refluk \\
\hline 0,5 & 100 & 58,5340 & 69,1099 & 25,5484 & 30,1645 \\
1 & 100 & 59,5811 & 97,9057 & 26,0055 & 42,7331 \\
3 & 100 & 85,3054 & 98,2199 & 37,2334 & 42,8702 \\
5 & 100 & 86,9109 & 96,4397 & 37,9342 & 42,0932 \\
9 & 100 & 88,9005 & 97,9057 & 38,8026 & 42,7331 \\
11 & 100 & 93,0890 & 99,7905 & 40,6307 & 43,5558 \\
13 & 100 & 94,5898 & 99,7905 & 41,2858 & 43,5558 \\
\hline
\end{tabular}


Data dari Tabel 3 dan Gambar 4 dapat dilihat adanya perubahan signifikan dan dibuat grafik sehingga dapat diketahui pada waktu ke berapa alang-alang dapat mengadsorpsi zat warna methylene blue. Dimana akan disajikan dalam bentuk grafik hubungan antara waktu kontak $(\mathrm{t})$ dengan kapasitas adsorpsi (q).

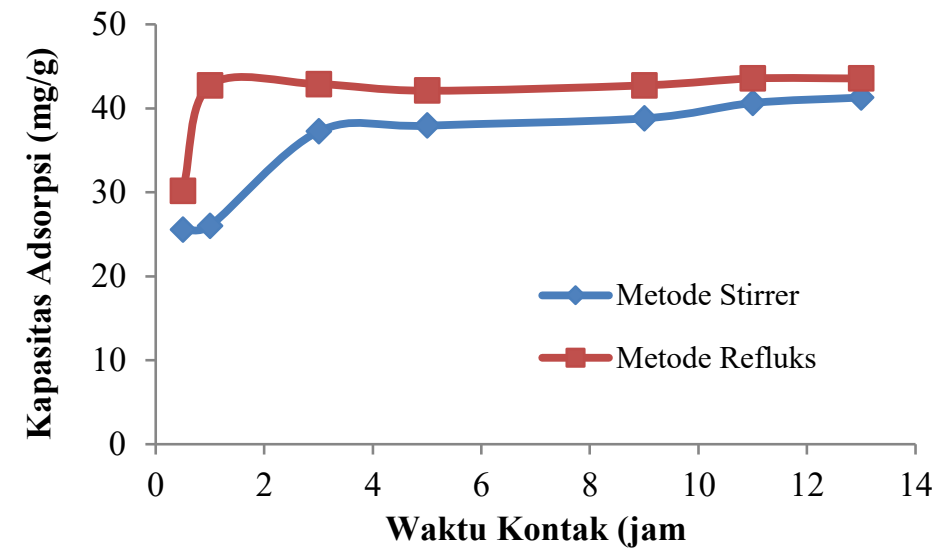

Gambar 4. Kurva Menunjukkan Waktu Kontak Optimum

Waktu kontak optimum tercapai pada saat 3 jam untuk metode stirrer dan 1 jam untuk metode refluk yang menghasilkan daya serap rata-rata keduanya secara berturut-turut sebesar $37,2334 \mathrm{mg} / \mathrm{g}$ dan $42,7331 \mathrm{mg} / \mathrm{g}$. Waktu kontak kurang dari 3 jam untuk metode stirrer dan 1 jam untuk metode refluk penyerapan dari alang-alang belum maksimal atau adsorben tersebut belum mencapai titik jenuh. Sedangkan setelah waktu optimum teersebut terlihat tidak ada kenaikan ataupun penurunan yang signifikan. Hal ini menunjukkan bahwa danya proses desorpsi dimana pori dalam adsorben alngalang telah terisi penuh maksimal sehingga tidak ada proses adsorpsi selanjutnya. Penelitian ini bertujuan untuk menentukan model kinetika yang sesuai pada proses adsorpsi zat warna methylene blue dengan melihat daya serap selulosa alang-alang dalam berbagai varaisi waktu kontak. Analisa kinetika didasarkan pada kinetika orde nol, orde satu, dan orde dua (Tabel 4).

TABEL 4. Penentuan Laju Kinetika Adsorpsi

\begin{tabular}{ccccc}
\hline Kinetika & \multicolumn{3}{c}{$\mathbf{R}^{\mathbf{2}}$} & \multicolumn{2}{c}{ K } \\
\cline { 2 - 5 } Adsorpsi & Stirrer & Refluks & Stirrer & Refluks \\
\hline Orde 0 & 0,731 & 0,306 & 2.303 & 1.080 \\
Orde 1 & 0,888 & 0,679 & 0,150 & 0,285 \\
Orde 2 & 0,926 & 0,688 & 0,013 & 0,412 \\
\hline
\end{tabular}

Tabel diatas menunjukkan bahwa model kinetika yang sesuai yaitu pada reaksi orde dua. Mekanisme adsorpsi yang terjadi dimana kecepatan adsorpsi berbanding lurus dengan dua konsentrasi pengikutnya atau satu pengikut berpangkat dua[9].

\subsection{Pengaruh Variasi Konsentrasi}

Kandungan adsorben alang-alang yang berfungsi sebagai adsorben adalah selulosa. Kemampuan selulosa untuk mengadakan interaksi dengan zat warna methylene blue disebabkan senyawa tersebut mengandung gugus fungsional yaitu gugus hidroksil dan asam karboksilat. Mekanisme reaksi pada umumnya dapat digambarkan sebagai penyerapan unsur positif pada zat warna reaktif terhadap gugus hidroksil pada selulosa yang terionisasi. 


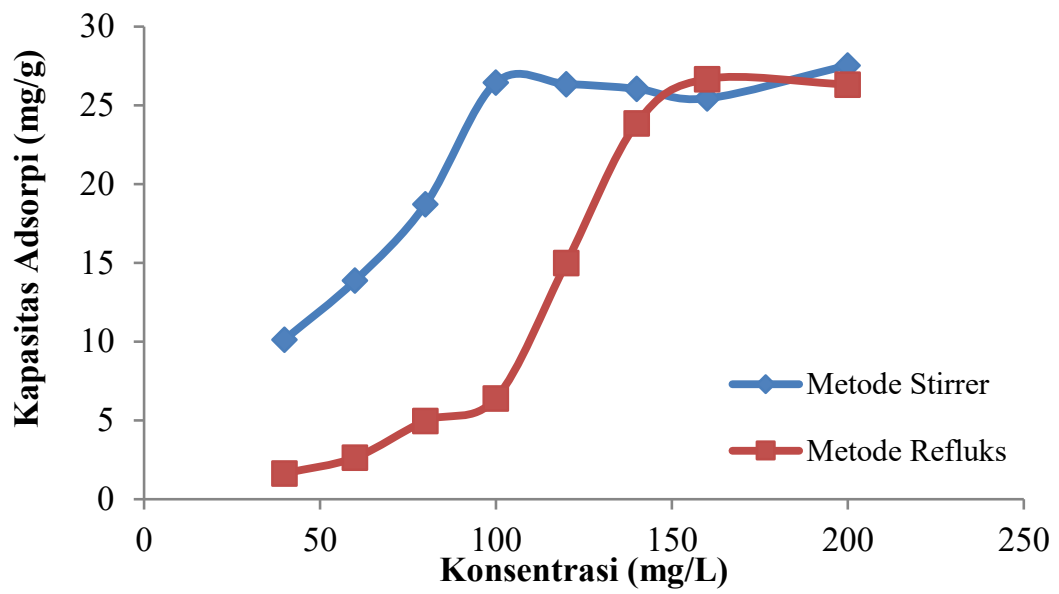

Gambar 5. Kurva Hubungan antara Kapasitas Adsorpsi dengan Konsentrasi

Semakin besar konsentrsai zat warna methylene blue, semakin besar konsentrasi adsorpsi yang diperoleh (Gambar 5). Hal ini karena jika konsentrasi methylen blue semakin besar dengan adanya senyawa methylene blue yang terkandung dalam zat warna tersebut juga semakin besar, sehingga adsorbat mampu terserap oleh adsorben alang-alang semakin banyak dalam bentuk kapasitas adsorpsi dengan satuan $\mathrm{mg} / \mathrm{g}$.

Konsentrasi optimum tercapai pada saat konsentrasi $100 \mathrm{mg} / \mathrm{L}$ untuk metode stirrer dan 160 $\mathrm{mg} / \mathrm{L}$ untuk metode refluk yang menghasilkan daya serap rata-rata keduanya secara berturut-turut sebesar 26,4472 mg/g dan 26,6758 mg/g. Konsentrasi yanglebih dari itu terlihat tidak ada kenaikan ataupun penurunan yang signifikan. Hal ini menunjukkan bahwa danya proses desorpsi dimana pori dalam adsorben alng-alang telah terisi penuh maksimal sehingga tidak ada proses adsorpsi selanjutnya.

\subsubsection{Isoterm Adsorpsi}

Penentuan isoterm adsorpsi (Tabel 5) berfungsi untuk mengetahui jenis adsorpsi yang terjadi sehingga proses adsorpsi terjadi. Iosterm adsorpsi methylene blue oleh alang-alang dapat ditentukan dengan membandingkan persamaan regresi linear dan koefisien determinasi $\left(\mathrm{R}^{2}\right)$.

TABEL 5. Hasil Pengukuran Isoterm Adsorpsi

\begin{tabular}{cccc}
\hline Isoterm & Plot graph & \multicolumn{2}{c}{$\mathbf{R}^{2}$} \\
\cline { 3 - 4 } Langmuir & $\frac{C_{e}}{q_{e}} v s C_{e}$ & Stirrer & Refluk \\
Freundlich & $\log q_{e} v \operatorname{sog} C_{e}$ & 0,991 & 0,362 \\
\hline
\end{tabular}

Berdasarkan hasil yang diperoleh nilai dari pengukuran isoterm adsorpsi dari metode stirrer lebih cenderung menggunkan prinsip Langmuir yang dkembangkan bentuk permukaan adsorben yang bersifat homogen karena nilai koefisien determinasi sebesar 0,991, mendekati 1. Sedangkan untuk metode refluks tidak menerapkan prinsip isoterm dari keduanya. Hal ini disebabkan karena rusaknya permukaan pada metode refluks pada proses pemanasan.

\subsection{Penentuan LOD dan LOQ}

LOD merupakan nilai konsentrasi analit terkecil yang mampu menghasilkan signal cukup besar sehingga mampu terdeteksi. LOQ adalah konsentrasi analit yang menghasilkan signal lebih besar dari blanko atau konsentrasi terkecil analit dalam sampel yang masih bisa diukur dengan menggunakan presisi dan akurasi yang baik, sesuai kondisi prosedur yang telah disepakati[10]. Nilai LOD dan LOQ penelitian yang menggunakan metode kurva kalibrasi merupakan nilai konsentrasi 
Huda et al., Ind. J. Chem. Anal., Vol. 01, No 01, 2018, pp. 09-19

terkecil analit yang dapat diukur oleh instrumen. Penentuan LOD dan LOQ dengan blanko pada analisis kadar kafein dalam sampel kopi dengan spektrofotometri UV-Vis single beam didapatkan data sebagai seperti yang ditunjukan pada Tabel 6.

TABEL 6. Penentuan LOD dan LOQ

\begin{tabular}{cccc}
\hline $\begin{array}{c}\text { Cethylene Blue } \\
(\mathbf{p p m})\end{array}$ & Absorbansi & $\mathbf{Y i}$ & $(\mathbf{y}-\mathbf{y i})^{\wedge \mathbf{2}}$ \\
\hline 0 & 0 & 0,418 & 0,1747 \\
1 & 0,22 & 0,418 & 0,3387 \\
2 & 0,418 & 0,418 & 2,5027 \\
3 & 0,666 & 0,418 & 6,6667 \\
4 & 0,892 & 0,418 & 12,831 \\
5 & 1,079 & 0,418 & 20,995 \\
\hline & Jumlah & 43,508 \\
\hline
\end{tabular}

Besarnya standar deviasi residual dapat dihitung dengan persamaan 1.

$$
\mathrm{S}(\mathrm{y} / \mathrm{x})=\sqrt{\frac{\sum(y-y i)^{2}}{n-2}}
$$

Berdasarkan hasil perhitungan diperoleh nilai limit deteksi dengan spektrofotometri UV-Vis adalah sebesar $0,1924 \mathrm{mg} / \mathrm{L}$. Nilai ini menunjukkan jumlah analit terkecil yang masih dapat terukur oleh spektrofotometri UV-Vis. Nilai LOD yang diperoleh tersebut merupakan jumlah terkecil methylene blue dalam sampel yang dapat dideteksi dan masih memberikan respon yang signifikan pada alat spektrofotometer UV-Vis. Nilai LOQ yang diperoleh sebesar $0,6414 \mathrm{mg} / \mathrm{L}$, artinya kuantitas terkecil methylene blue dalam sampel yang masih dapat memenuhi kriteria cermat dan seksama adalah sebesar $0,6414 \mathrm{mg} / \mathrm{L}$. Konsentrasi tersebut merupakan konsentrasi terkecil yang tidak menimbulkan bias dalam perhitungan.

\subsection{Penentuan FTIR}

Gugus fungsi yang terdapat dalam selulosa alang-alang dapat diketahui dengan pengukuran menggunakan spektrofotometer infra merah (FTIR). Pengukuran dilakukan pada sampel alang-alang sebelum dan sesudah adsorpsi pada $\mathrm{pH}$, waktu kontak, dan konsentrasi optimum. Analisis FTIR dilakukan dari bilangan gelombang 4000-400 $\mathrm{cm}^{-1}$, dimana pada rentang bilangan gelombang tersebut terdapat gugus-gugus fungsi serta sidik jari yang dimiliki oleh selulosa alang-alang. Pengujian ini dilakukan dengan analit pada suasana $\mathrm{pH}$ optimum (9) selama waktu kontak optimum, pada konsentrasi optimum tiap metode nya. Spektra FTIR alang-alang sebelum dan setelah adsorpsi dapat dilihat pada Gambar 6 dibawah ini. 


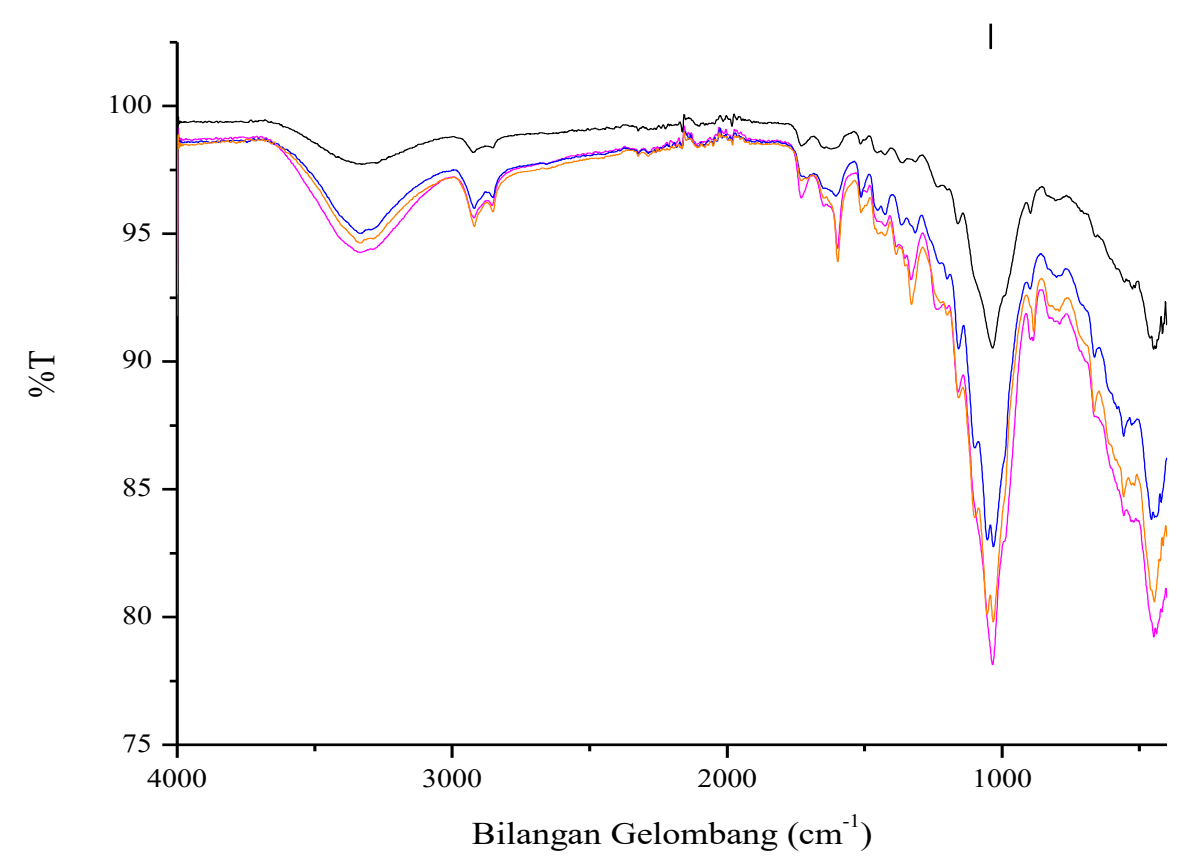

Gambar 6. Spektra FTIR Struktur Selulosa Aalng-alang

Hasil pengamatan dengan FTIR tampak adanya puncak-puncak yang muncul. Spektra yang dihasilkan pada alang-alang metode stirrer dan refluks baik sebelum maupun sesudah adsorpsi tidak ada perbedaan yang signifikan dan hanya sedikit terjadi pergeseran bilangan gelombang. Hasil ini mengindikasikan bahwa dengan adanya proses persiapan metode yang berbeda terhadap adsorpsi tidak mengakibatkan hilangnya gugus fungsi yang terdapat didalam alang-alang. Gugus fungsi yang terdapat pada selulosa dari alang alang terdapat pada Tabel 7 dan 8 .

TABEL 7. Spektra Gugus Fungsi Selulosa pada Alang-Alang Metode Stirrer

\begin{tabular}{cccccc}
\hline \multirow{2}{*}{ Gugus Fungsi } & \multirow{2}{*}{$\left(\mathbf{c m}^{-\mathbf{1}}\right)$} & \multicolumn{4}{c}{ Metode Stirrer } \\
\cline { 3 - 6 } & & \multicolumn{2}{c}{ Sebelum Adsorpsi } & \multicolumn{2}{c}{ Setelah Adsorpsi } \\
\cline { 3 - 5 } & & $\mathbf{v ~ ( \mathbf { c m } ^ { - 1 } )}$ & $\mathbf{\%} \mathbf{T}$ & $\mathbf{v}\left(\mathbf{c m}^{-\mathbf{1}}\right)$ & $\mathbf{\%} \mathbf{T}$ \\
\hline O-H & $3900-3000$ & 3319,03 & 97,72 & 3334 & 94,26 \\
C-H & $3150-2600$ & 2922,84 & 98,18 & 2920,58 & 95,62 \\
C-O & $1300-890$ & 1034,48 & 90,51 & 1034,62 & 78,12 \\
\hline
\end{tabular}

TABEL 8. Spektra Gugus Fungsi Selulosa pada Alang-Alang Metode Refluks

\begin{tabular}{cccccc}
\hline \multirow{2}{*}{ Gugus Fungsi } & \multirow{2}{*}{$\left(\mathbf{c m}^{-1}\right)$} & \multicolumn{4}{c}{ Metode Refluks } \\
\cline { 3 - 5 } & & \multicolumn{2}{c}{ Sebelum Adsorpsi } & \multicolumn{2}{c}{ Setelah Adsorpsi } \\
\cline { 3 - 5 } & & $\mathbf{v}\left(\mathbf{c m}^{-1}\right)$ & $\mathbf{\% T}$ & $\mathbf{v}\left(\mathbf{c m}^{-1}\right)$ & $\mathbf{\% T}$ \\
\hline O-H & $3900-3000$ & 3331,07 & 95,02 & 3331,16 & 94,65 \\
C-H & $3150-2600$ & 2919,7 & 95,39 & 2918,96 & 95,68 \\
C-O & $1300-890$ & 1031,78 & 82,73 & 1032,03 & 79,78 \\
\hline
\end{tabular}

Konsentrasi zat warna yang terserap sangat kecil, mengakibatkan gugus-gugus fungsi dai zat warna tertutupi oleh gugus fungsi dari selulosa sehingga tidak terdeteksi oleh FTIR. 
Huda et al., Ind. J. Chem. Anal., Vol. 01, No 01, 2018, pp. 09-19

\section{KESIMPULAN}

Berdasarkan hasil penelitian yang telah dilakukan dapat disimpulkan bahwa proses degradasi zat warna methylene blue optimum pada $\mathrm{pH} 9$ atau suasana basa dengan laju kinetika pada orde dua dan cenderung menggunakan interaksi multileyer atau prinsip isoterm adsorpsi freundlich. Interaksi adasorpsi yang terjadi karena adanya adsorpsi fisika. Kapasitas adsorpsi dari masing-masing metode secara berturut-turut sebsar $26,4472 \mathrm{mg} / \mathrm{g}$ dan $26,6758 \mathrm{mg} / \mathrm{g}$. Adsorpsi alang-alang terhadap zat warna methylene blue tidak berpengaruh pada struktur selulosa dari alang-alang dan gugus yang terdapat pada alang-alang yaitu $\mathrm{O}-\mathrm{H}, \mathrm{C}-\mathrm{H}$, dan $\mathrm{C}-\mathrm{O}$.

\section{Daftar Pustaka}

[1] P. P. Atmaji., Wahyu dan P. Edi., "Daur Ulang Limbah Hasil Pewarnaan Industri Tekstil," Jurnal Sains dan Teknologi Indonesia 1 (4):1-5, 1999.

[2] T. Kusumaningsih, Desi S.H., dan Yuni L, "Pembuatan Mikrokapsul Kitosan Gel Terambung Silang Etilen Glikol Diglisidil Eter (Psf-Edge-Cts) sebagai Adsorben Zat Warna Procion Red Mx 8b," Alchemy J. Penelitian Kimia. 8(1). Hal: 47-56, 2012.

[3] S. Susi, "Penentuan Pektin Secara Spektrofotometri dalam Bahan Baku Bukan Kayu," Berita Selulosa. 19(1). 1-4, 1983.

[4] E. Djauhariya, dan Hernani, Gulma Berkhasiat Obat. Cetakan 1, Jakarta: Penerbit Swadaya, 2004 .

[5] O. Hamdaoui., Chiha, M., Removal of Mthylene Blue from Aqueous Solutions by Wheat Bran. Acta Chim. Slov. 54. 407-418, 2006.

[6] A.P. Rizki, Isoterm Langmuir, Model Kinetika dan Penentuan Laju Reaksi Adsorpsi Besi dengan Arang Aktif dari Ampas Kopi, Jurusan Teknik Kimia. Fakultas Teknik, Universitas Mulawarman, 2015.

[7] I.G. Ganjar, Kimia Farmasi Analisis, Yogyakarta: Pustaka Pelajar, 2008.

[8] I. Noviyana, Peningkatan Kapasitas Adsorpsi Batu Bara Muda Melalui Pengayaan Kadar Oksigen dengan Menggunakan Hidrogen Peroksida.(Doctoral dissertation, Universitas Pendidikan Indonesia), 2013.

[9] B. Emrah., Ozacar, Mahmut., Sengil, Ayhan., Adsorption of Malachite Green Onto Bentonite : Equilibrium and Kinethics Studies and Process Design, Microporous and Mesoporous Materials, Elsevier, 115.234-256, 2008.

[10] Riyanto, Validasi dan Verifikasi Metode Uji Sesuai dengan ISO/IEC 17025 Laboratorium Pengujian dan Kalibrasi, Yogyakarta : Deepublish, 2014. 